\title{
Ecological control of the gastrointestinal tract. The role of probiotic flora
}

\section{The "new" lifestyle-a threat to health?}

It is increasingly evident that human diseases are most often related to lifestyle, and should in theory be preventable. The stress of modern life, our reduced physical activity, and our consumption of manipulated and processed foods, and of chemicals - including pharmaceuticals-all contribute to our decreasing resistance to disease. Much evidence supports the fact that our genes, adapted during millions of years to the lifestyle of our prehistoric ancestors, tolerate poorly the dramatic changes in lifestyle that have occurred, especially in food habits during the past 100 years. ${ }^{1}$ Changes in food habits in Western countries that no doubt constitute stresses to the human body and that may predispose to inflammatory, infectious, ulcerative, degenerative, and neoplastic diseases include the following: the consumption of $100 \mathrm{lb}$ refined sugar per individual per year; the 10-fold increase in sodium consumption; the fourfold increase in consumption of saturated fat; the doubled consumption of cholesterol; a much reduced consumption of vegetable fibres, and of minerals such as potassium, magnesium, calcium, and chromium; and a considerable reduction in consumption of $n-3$ fats, membrane lipids, vitamins, and antioxidants. In severe disease, important food ingredients, such as arginine, glutamine, taurine, nucleic acids, vitamins, and antioxidants, such as glutathione, are often not supplied in large enough quantities.

Perhaps even more important than the decrease in these food ingredients, is the fact that prehistoric food contained several thousand times more bacteria, mainly the so called probiotic bacteria. Prehistoric methods of food preservation were either drying, or, more commonly, storing in holes dug into the ground, where the food became naturally fermented. This is how Stone Age man learned to produce most of our still common fermented foods, such as beer, wine, green olives, and sauerkraut. Our modern lifestyle has dramatically reduced the availability of foods produced by natural fermentation. After the early identification of microbes, bacteria were regarded mainly as a source of disease, and unwanted in commercially manufactured food. Furthermore, the desire of the food industry to prolong shelf life promoted alternative production methods such as the use of enzymes instead of live bacteria. Combined with extensive hygiene measures practised during delivery and in child care, children in Western societies may have difficulty developing a satisfactory protective indigenous gut flora. It is not known, but suspected, that this could be connected to the increasing incidence of allergy (and infections) seen among Western children. ${ }^{2-4}$ Lindeberg ${ }^{5}$ recently published a series of studies of an ethnic group in New Guinea with a dramatically different diet to that of people in the Western world. This diet contained no processed foods like butter, margarine, lard, oils, refined sugar, or alcohol. Instead, the group's diet was rich in fibre, water, vitamins, minerals, and n-3 fats such as docosahexaenoic acid (DHA) and eicosapentaenoic acid (EPA). Despite the fact that about $80 \%$ of the population smokes and has a heavy consumption of saturated fat from coconut, cerebrocardiovascular diseases are virtually absent and the incidence of diabetes and cancer is very low.

\section{The gastrointestinal tract-the port of infectious diseases}

The condition and function of the gastrointestinal (GI) tract are essential to our well being. After the respiratory tract, the GI tract constitutes the second largest body surface area, described to be somewhere between 250 and 400 $\mathrm{m}^{2}$, or comparable in size to a tennis court. During a normal lifetime 60 tons of food pass through this canal, which is important for well being, but also constitutes an enormous threat to the integrity of the digestive tract and the whole body. It is not surprising, therefore, that this organ is often affected by inflammatory diseases and cancer. The continuous challenges to the GI surfaces might be why most of the surface cells have a rapid turnover; most are replaced after three to four days in man and sometimes earlier in animals. Furthermore, the surface is protected by large quantities of important secretions, from saliva in the oral cavity to colonic secretion in the large bowel. These secretions contain factors of great importance for the lubrication of the mucosa and for functions of the GI tract but also hundreds of ingredients of importance for intraluminal microbial defence. The secretory functions are extremely sensitive to foreign chemicals. About $50 \%$ of the 2000 pharmaceutical drugs registered in Sweden have reported GI side effects, for example, mouth dryness, nausea, vomiting, diarrhoea, and obstipation. It is hoped that future medicine will be more restrictive in the use of pharmaceuticals in general, and will use drugs with as few side effects as possible. At present, physicians often choose the most effective drug without regard to side effects. A wise alternative could be to choose a somewhat less effective drug, if it has fewer or no side effects.

\section{GI flora are crucial to well being}

The GI tract harbours a rich flora of more than 500 different bacterial species, some of which have important health functions. The human body contains 10 times more protective indigenous flora than do eucaryotic cells. ${ }^{6}$ It has been suggested that this flora be regarded as part of the human body. The fact that different medical treatments cause serious derangements in the structure and function of the probiotic flora has been ignored in the past. This includes the administration of antibiotics, cytostatics, and irradiation, as well as failure to provide sufficient enteral nutrients for the flora. I have previously discussed the preventive flora and its specific role in clinical 
immunonutrition. ${ }^{7-10}$ In this review I will mainly consider the role of the flora per se in the prevention and treatment of infections. Special emphasis will be given to the role of probiotic bacteria as an alternative to antibiotics - that is, microbial interference treatment (MIT).

\section{Nosocomial infections-a remaining threat}

Hospitals provide unique ecological settings for the development of infections. Schwartz ${ }^{11}$ noted recently that in the United States 2.1 million patients- $6 \%$ of all hospital admissions-develop nosocomial infections. The situation is likely to be similar or worse in the European Union states. Patients with depressed immune function are most at risk. More than half (54\%) of hospital infections occur in patients over the age of 65 , despite the fact that this group represents only one third of hospital admissions. One half of patients with neutropenia $(48.3 \%)^{11}$ and one half of transplantation patients (liver transplantation $53.7 \%)^{12}$ contract nosocomial infections, which are often life threatening. As pointed out by Schwartz, ${ }^{11}$ the infection rate in connection with surgery is still high; it is for example, $21 \%$ in gastric surgery, $19 \%$ in bowel surgery, $18 \%$ in craniotomies, and $11 \%$ in coronary artery bypass grafts. Furthermore, patients with severe diseases such as acute pancreatitis, inflammatory bowel disease, and infection with HIV or AIDS suffer an unacceptably high rate of opportunistic infections. In haematological malignancies, infections constitute the leading cause of morbidity, and $85 \%$ of these infections are caused by only a few families of microorganisms, for example, Enterobacteriaceae, Pseudomonaceae, and Micrococcae. ${ }^{13}$ These potentially pathogenic microorganisms (PPMs) occur normally in healthy individuals as a subflora in the GI tract, but can become dominant by overgrowth in sick patients, especially after antibiotic treatment. For example, it has been shown that the composition of the oral microflora changes markedly during combined antineoplastic and antimicrobial treatment leading to a significantly increased presence of PPMs. ${ }^{13-15}$ Only admission to hospital results in a documented increase in the carriage of Klebsiella.

Microbial interference treatment is highly desirable Probiotic bacteria are live microorganisms belonging to the natural flora with low or no pathogenicity, but with functions of importance to the health and well being of the host. Maintenance of this ecological flora is important in preventing disease, especially infections. It is increasingly accepted that probiotic bacteria are effective tools for controlling overgrowth of PPMs of bacterial, viral, and fungal origin. ${ }^{16}$ Probiotic bacteria can control various enteric pathogens such as Salmonella typhimurium, ${ }^{17}$ Shigella, ${ }^{18}$ Clostridium difficile, ${ }^{19}$ Campylobacter jejuni, ${ }^{20}$ and Escherichia coli. $^{21}$ They may also provide important protection against urogenital pathogens such as Gardnerella vaginalis, Bacteroides bivius, Candida albicans, and Chlamydia trachomatis. ${ }^{22}{ }^{23}$ Much evidence thus supports the expectation that probiotic bacteria can be effective weapons for preventing and treating many microbial infections.

By 1877 Pasteur and Joubert ${ }^{24}$ had already observed the antagonistic interaction between some bacterial strains, and by the turn of the century Metchnikoff ${ }^{25}$ had discussed the possibility of bacterial replacement therapy. As recently pointed out by Jack et al, ${ }^{26}$ ever since these observations there has been a small group of scientists who have stubbornly promoted bacteriotherapy and MIT as methods for preventing infections and some other diseases. During the past 50 years, however, interest has been focused on the use of chemotherapeutics and antibiotics for these purposes: a clinical field of study which, during almost half a century, developed with enormous speed.
There are several reasons for the renewed and more general interest in infection control through MIT, including the following:

(1) A recognition that antibiotic therapy has not been successful to the extent one might have expected. Although it has no doubt solved some medical problems, it has also created some new ones.

(2) An increasing awareness of the fact that antibiotic treatment deranges the protective flora, and thereby predisposes to later infections.

(3) An increasing fear of antibiotic resistant microbial strains, as a result of widespread overprescription and misuse of antibiotics.

(4) A fear that industry will no longer be able to develop effective antibiotics at a sufficient rate to compete with the development of microbial resistance to old antibiotics.

(5) A widespread public interest in ecological methods.

Despite dramatic advances in intensive care technology and in the development of new antibiotics, the mortality associated with Gram negative bacteraemia has continued to remain between $20 \%$ and $40 \%{ }^{27}$ and the leading causes so far have been $E$ coli, Klebsiella pneumoniae, other Enterobacteria, and Pseudomonas aeruginosa. Thus the mortality reported today is about the same as that during the preantibiotic era, ${ }^{28}$ despite more than 50 years of treatment development. There is very little hope that further treatment developments along the existing paradigms of treatment will dramatically change this situation. ${ }^{29}$ There is a great need for new treatments.

\section{World Health Organisation recommends MIT}

The World Health Organisation (WHO) recently held a conference to discuss the increase in resistance to antibiotics, which today is "a major public health problem in both developed and developing countries throughout the world". ${ }^{30}$ The WHO Scientific Working Group states: "The incidence has increased at an alarming pace in recent years and is expected to increase at a similar or even greater rate in the future as antimicrobial agents continue to lose their effectiveness" ${ }^{30}$ In addition to being a serious threat to human health, resistance to antimicrobial agents is "a significant economic threat as well". ${ }^{30} \mathrm{With}$ this in mind the WHO recommends global programmes to reduce the use of antibiotics "in animals, plants and fishes, for promoting livestock growth" ${ }^{30}$ and in human medicine, and recommends increased efforts to prevent disease "through increasing immunisation coverage with existing vaccines, and through the development of newer, more effective and safer vaccines. In addition, several older forms of therapy, including bacterial interference, serum therapy and the use of macrophages to kill organisms, may be worth reconsidering". ${ }^{30}$

\section{Lactic acid bacteria-new research possibilities}

It has been shown that lactobacilli are especially suitable for MIT, and superb in counteracting Gram negative bacteria. In the past, however, excellent results have often been difficult to reproduce. Sanders ${ }^{31}$ recently published a critical review of the role of lactic acid bacteria as a promoter of human health. She concludes that "this research area has suffered from a lack of coordinated efforts between the clinicians and the microbiologists, and that differences in strains, levels, model system and stringency of data interpretation lead to apparent inconsistencies in conclusions from published research". ${ }^{30}$ I fully agree. This explains why MIT has never received full acceptance by the medical community. Despite the fact that the concept of MIT has been known for more than 100 years, it is still regarded as being in its infancy. Despite hundreds of 
publications, only a few seem to contribute convincingly to our knowledge of health effects in humans, since most studies have been uncontrolled, and therefore not reproducible by other study groups or in other settings.

The vast interest in health effects of lactic cultures is largely lacking reliable support from solid clinical studies, and many claimed functions are unproven. Even identification of different probiotic bacterial strains has often been unreliable, which has made it impossible to prove the presence in the microflora of the strain administered. Repeat studies, thought to be conducted with the same lactobacillus, have probably often been performed with different bacterial strains. New taxonomic instruments offer great hopes that lactic acid bacteria research in the future will be better structured.

\section{Species specificity and mucosal adherence have been neglected}

The need for probiotic bacteria to adhere to mucosal surfaces in order to colonise and exert interference with other microorganisms, as well as the importance of host specificity, has in the past not received enough attention, although these variables are likely key factors in microbial interference. One can assume that the human mucosa will tolerate colonisation only with bacteria with which it has had a symbiotic coexistence, possibly during millions of years, whereas other bacteria will be quickly rejected. As noted by Isolauri et $a l^{32}$ the ability of lactobacilli to adhere to epithelial cells and thereby temporarily colonise the gut is most probably of crucial importance. Barrow et $a l^{33} \mathrm{dem}-$ onstrated in 1980 that adhesion of lactobacilli to the cells of the host organisms is species specific. It had been assumed until recently that if a lactobacillus continued to be excreted with faeces several days after the conclusion of its supply, it was likely to be mucosa adhesive. This is, however, not necessarily so. Currently the only way to prove true mucosa adhesiveness seems to be to repeat studies with colonoscopy assisted biopsies. ${ }^{34} \mathrm{~A}$ simpler and less expensive alternative might be to study mucosa adherence in vitro by using human epithelial cell lines such as Caco-2 and HT-29. ${ }^{35} 36$ The extent to which in vitro results correspond with in vivo conditions remains, however, to be confirmed.

It has not been easy to find strains capable of colonising the human intestinal mucosa, when attempted over short time periods such as a few days. ${ }^{37-40}$ Much evidence supports the observations by Chanviere et $a l^{35}$ that only few of the lactobacillus strains usually used commercially are mucosa adhesive on Caco-2 and HT-29 cells and also in vivo in humans. For example, common commercial dairy strains such as L bulgaricus and L acidophilus are not adhesive to Caco- 2 cells nor in vivo in humans. Also the bifidobacterial strains tried so far are either not adhesive or only slightly adhesive. ${ }^{35}$ Recently, however, a special Lactobacillus strain called LA1 has been shown to possess the ability to adhere to human enterocytes such as Caco- 2 cells in culture, ${ }^{41}$ which was further demonstrated by electron microscopy. So far, however, few clinical effects have been shown using this $L$ acidophilus strain.

The demonstration by Elo et $a l^{42}$ that Lactobacillus strain GG has consistent adhesive properties that are independent of freeze drying was a significant step forward. This finding explains earlier observations by Goldin et $a l^{43}$ that Lactobacillus strain GG persists in $87 \%$ of faeces after four days and in 33\% after seven days. Ling et al ${ }^{44}$ found Lactobacillus strain GG in $28 \%$ of faeces as late as two weeks after the supply of the strain had been discontinued. Adlerberth $e t a b^{36}$ using the HT-29 cell line, showed recently that several strains of $L$ plantarum display strong, sometimes unique adhesiveness. Interestingly, these strains adhere to mannose containing glycoproteins, which has previously been demonstrated for enterobacteria such as $E$ coli, Enterobacter, Salmonella, and Shigella, as well as Vibrio cholerae. These findings seem to parallel earlier findings obtained through studies of biopsy specimens obtained with repeat endoscopy. ${ }^{34}$ Until now, however, intestinal mucosal adhesiveness had not been convincingly shown for any lactobacilli clinically tried in humans other than $L$ rhamnosus, strain GG and strain 271 , L plantarum strains 299 and $299 \mathrm{~V}$, and recently $L$ acidophilus strain LA1. It is promising that evidence of strong clinical effects is fast accumulating for most of these lactobacillus strains.

Even non-adhesive lactobacilli, during their passage through the GI tract, may have some short lived, but not always reproducible effects. Halpern et $a l^{45}$ did not observe any beneficial influence of daily consumption of $450 \mathrm{~g}$ of yoghurt on lipid metabolism, including serum cholesterol, but did observe a significant and potentially beneficial increase in serum calcium concentrations and a most interesting increase in production of $\gamma$-interferon by isolated $\mathrm{T}$ cells. Increases in $\gamma$-interferon are associated with improved immune defence and are most likely lactobacillus induced. However, stronger metabolic and antimicrobial effects can be expected from adhesive species specific bacteria such as $L$ plantarum and L rhamnosus species. It is interesting that the same bacteria when used in functional food products appear to have significantly longer shelf lives than other lactobacilli including $L$ acidophilus. ${ }^{46}$

\section{Lactobacillus rhamnosus-a clinically promising lactobacillus}

L rhamnosus strain GG (ATCC 53103) is by far the most thouroughly explored of all lactic acid bacteria so far correctly taxonomically identified. It has been clinically tried and is extensively regarded as being suitable for MIT. The strain was originally identified as $L$ acidophilus and later named $L$ casei $\mathrm{GG}$, but has recently been identified as $L$ rhamnosus. ${ }^{46}$ Lactobacillus strain GG has been found to decrease faecel $\beta$-glucuronidase, nitroreductase, and hydrolase activities ${ }^{46}$ and has also been suggested to have cancer preventive effects. It was recently shown effectively to shorten acute rotavirus diarrhoea in a group of 42 well nourished children, given two doses of $10^{10}$ lactobacilli every day for five days. ${ }^{47}$ Furthermore, Lactobacillus strain GG has proven to be effective in preventing and treating diarrhoea in premature infants, ${ }^{49}$ newborns,${ }^{50}$ children,${ }^{51}$ and travellers. ${ }^{43}$ It has also been reported to be effective against severe intestinal infections such as Clostridium difficile. $^{5354}$ Strain GG is an ingredient in dairy products, and has been available in the Finnish market since 1990; it is also being introduced into Sweden and other countries. In Finland about one million kilograms of strain GG containing milk and yoghurts are consumed per one million inhabitants per year. ${ }^{55}$ Strain GG has been shown to be safe when administered to humans. ${ }^{56}$

Another L rhamnosus strain presently being explored in Sweden is $L$ rhamnosus 271 . Although this strain has not demonstrated, when compared with L plantarum, the same great ability to adhere to human mucosa cells in vitro, ${ }^{36}$ it has been recovered in large amounts in faeces of healthy volunteers consuming the bacteria, and found in large amounts in faeces seven days after its administration has ceased. ${ }^{57}$ Furthermore, this $L$ rhamnosus strain is made available commercially in milk and yoghurt.

\section{$L$ plantarum-a regulator of GI function?}

$L$ plantarum is a member of the facultative heterofermentative group of lactobacilli. Many different $L$ plantarum strains have been isolated from traditional habitats of lactobacilli, such as plants, vegetables, fish, meat, and other 
fermented foods. L plantarum produces acetate in addition to lactate under anaerobic conditions. It also possesses pathways for converting malate, tartrate, and citrate to lactate or acetate, ${ }^{58}$ and can deaminate arginine to ornithine, and serine to pyruvate. ${ }^{59}$ Pyruvate is converted to both L-(+) and $\mathrm{D}-(-)$ lactate. $L$ plantarum often contains plasmids, which might carry important fermentation enzymes. ${ }^{60}$ It has the unique ability to tolerate low $\mathrm{pH}$, which makes it the dominant species at the last step of natural fermentation. ${ }^{61}$ This is why $L$ plantarum is the dominant species in a range of fermented foods, including sour dough, sauerkraut, green olives, natural wines and beers, and many Third World staple foods, such as African ogi. During anaerobic storage of foods, such as meat, $L$ plantarum becomes the dominant flora, and is entitely dependent on the availability of glucose and arginine for its growth. ${ }^{62}$ Our ancestors consumed large amounts of $L$ plantarum; this practice was rather abruptly discontinued, at least in the Western world, with the introduction of modern processed food.

The most unique feature of $L$ plantarum is its ability to catabolise arginine, and generate nitric oxide. L plantarum is unable to degrade any amino acids other than tyrosine and arginine, but has six different pathways to degrade arginine, ${ }^{63}$ and nitric oxide is produced in all of them. This function is interrupted or at least depressed by antibiotic treatment. Administration of antibiotics such as neomycin, bacitracin, and polymyxin B is known to lead to reduced activity of intraluminal enzymes such as lysine, ornithine, and arginine decarboxylases. ${ }^{64}$ During anaerobic storage of foods such as meat, lactobacillus becomes the dominant flora, and these microorganisms are entirely dependent on the availability of glucose and arginine for their growth. ${ }^{64}$ Arginine is most likely one of, if not the most important NO donor for the GI tract. Moncada and his group ${ }^{65}$ suggested in 1992 that NO released by constitutive enzymes exerts a protective influence and that NO released by inducible enzymes is destructive to the GI tract. Normally, NO released in the GI tract by constitutive enzymes is involved in a series of important GI functions such as bacteriostasis, mucus secretion, regulation of motility and of splanchnic circulation, ${ }^{66}$ and in stimulation of GI immune functions. Acidified nitrate in the stomach functions as an NO donor, and most likely will effectively control Candida albicans, E coli, Shigella, Salmonella, Helicobacter pylori, amoebae, and parasites. ${ }^{66}{ }^{67}$ Nitric oxide is likely to have similar functions at the level of both the small and large intestine. It occurs via the arginine/NO function, and it might be that the disease controlling function of $L$ plantarum occurs over the arginine/NO pathway. Recent data suggest that $L$ plantarum, at least the human specific $L$ plantarum strains 299 and 299V, has a unique adhesiveness to the mucosa, ${ }^{36}$ and thereby builds an important biological shield to prevent overgrowth by PPMs and resulting microbial translocation. It seems logical to anticipate that the mechanism of this action is, at least to some extent, via the arginine/NO function.

Large amounts of endotoxin produced in the lumen of the GI tract have no serious effects on the body: to be damaging, endotoxins must be delivered at the mucosal surface. ${ }^{68}$ By preventing $E$ coli from adhering to the mucosa, $L$ plantarum effectively prevents endotoxins from being delivered into the body. In support of this theory are obervations in animals with induced peritonitis (caecal ligation and puncture) that antibiotics (gentamicin) can reduce the serum endotoxin titre, but that only a supply of lactobacillus totally prevents endotoxin from appearing in serum (Nobaek et al, unpublished observations). Because of the short half life of NO, it can be assumed that it will be effective only if produced at the level of the mucosa by mucosa adhesive bacteria such as L plantarum.

A supply of mucosa colonising L plantarum 299 and $299 \mathrm{~V}$ leads to a significant decrease in Gram negative anaerobes, Enterobacteriaceae, and also of sulphite reducing clostridia. ${ }^{69}$ These bacteria have shown a strong ability to counteract sepsis of gut origin and multiple organ failure but also infections such as Clostridium difficile. Several reviews have been published on this topic. ${ }^{7-10}$

\section{Nutrition influences PPM adherence and virulence}

Bacterial adherence is an important prerequisite for colonisation by pathogenic microorganisms and virulence manifestations. ${ }^{70}$ Pathogenic bacteria form a close association with the intestinal mucosa, which is the first step of bacterial infection ${ }^{41}$ and initation of infectious and sometimes also other diseases. As an example, the intestinal pathogenicity of Enterobacteriaceae seems to be directly related to the ability of this family to adhere to the intestinal mucosa. ${ }^{71}$ For endotoxin to reach its cellular target, it must be concentrated close to the surface, an event that occurs only when bacteria adhere. Ingestion of as much as $150 \mathrm{mg} E$ coli lipopolysaccharide does not seem to induce adverse systemic effects. ${ }^{72}$ Bacterial adherence is prevented by mucosal IgA responses. ${ }^{73}$ During stress, particularly enteral starvation, bacterial adherence seems to increase,${ }^{74}$ maybe as an adaptive response of the bacteria. Thus Gram negative bacteria, which colonise critically ill patients, express a higher ability to adhere ${ }^{75}$ than do those that colonise other patients. Spitz et $a l^{76}$ recently noted that of all the factors influencing adherence and virulence, a shortage of nutrients seems to evoke the most dramatic response. At the same time as luminal nutrient deprivation stresses the luminal bacteria and increases their adhesiveness, it also decreases mucosal IgA production. ${ }^{77}$ Enteral starvation occurs within a day of use of parenteral nutrition or chemically defined, so called astronaut diets, which are absorbed in the proximal small bowel, thus leaving too little substrate for the colonic microflora. Alverdy et al estimate that about a 10 -fold increase in bacterial permeability is necessary for a decrease in mucosal adherence to be observed. ${ }^{74}$ With the relation between enteral nutrition and virulence of PPMs in mind, it is not surprising that a $76 \%$ reduction in sepsis rate was observed when patients with abdominal trauma were fed enterally compared with parenterally. ${ }^{78}$ During the past few years great success has been achieved in postsurgical and post-trauma care by feeding these patients enterally. ${ }^{79}$ Evidence is also accumulating that the sepsis rate can be further reduced by adding special immunostimulatory nutrients such as arginine, glutamine, taurine, omega fats, and vitamin $\mathrm{E}$ to the formula. ${ }^{80-85} \mathrm{I}$ am convinced that an ecoimmunostimulatory enteral nutrition formula should also contain specific fibre or substrate for the bacteria, surfactants, and probiotic bacteria such as L plantarum 299 and $L$ rhamnosus. ${ }^{6-10}$

Stress is known to affect the composition of the intestinal preventive flora ${ }^{86}{ }^{87}$ Infants fed on artifical infant formulas have, in contrast to breastfed ones, a very low degree of colonisation with lactobacilli and bifidobacteria ${ }^{88}$ but high counts in enterococci, coliforms, and clostridia. ${ }^{8-90}$ This may relate to excessive hygiene measures during delivery in Western countries, which prevent transfer of anaerobic microflora from mother to infant. ${ }^{91}{ }^{92}$ It is also known that cosmonauts on return to Earth have lost their lactobacillus flora, especially L plantarum, which is partly replaced by a higher intestinal content of PPMs, changes attributed to stress and poor eating. ${ }^{93}$ It is likely that many people on earth have a similar lifestyle and could benefit from regular 
supplements of lactobacilli of human origin, such as those mentioned above.

\section{Enterococcus faecium-a new threat}

Although the microbial pattern in nosocomial infections has been stable during at least the past 100 years, dramatic changes have occured during the past 10 . The prevalence of the lactic acid bacterium Enterococcus, a nosocomial pathogen, has increased and now these bacteria are second only to $E$ coli ${ }^{94}$ During $1992-1994$ enterococci made up $41 / 108(30.6 \%)$ of all surgical intensive care bacteraemia episodes at Johns Hopkins institutions in Baltimore, ${ }^{96}$ with a mortality of $39 \%$. Enterococcus faecium in particular, but also $E$ faecalis, have become increasingly resistant to agents traditionally useful in the treatment of infectious diseases. ${ }^{1194}{ }^{96-103}$ Although in the Johns Hopkins study $100 \%$ of the $E$ faecalis was vancomycin sensitive, $71.4 \%$ of $E$ faecium was found to be vancomycin resistant. ${ }^{94}$ Vancomycin resistant $E$ faecium strains are rapidly emerging worldwide and have the prospect of being a large threat to humans, similar to HIV. Antibiotics are no longer a realistic alternative. Against a background such as this MIT should be considered and tried.

Lund University,

S BENGMARK

Ideon Research Centre,

Suite 230,

Beta Building,

S22370 Lund,

Sweden

1 Eaton SB, Konner M. Paleolithic nutrition. A consideration of its nature and current implications. N Engl F Med 1985;312:282-9.

2 Chandra RK. Prospective studies of the effect of breast feeding on the incidence of infection and allergy. Acta Pediatr 1979;68:691-4.

3 Hall MA, Cole CB, Smith SL, Fuller R, Rolles CJ. Factors influencing the presence of faecal lactobacilli in early infancy. Arch Dis Child 1990;65:1858.

4 Björkstén B. Risk factors in early childhood for the development of atopic disseases. Allergy 1994;49:400-7.

5 Lindeberg S. Apparent absence of cerebrocardiovascular disease in Melanesians [thesis]. Sweden: Lund University, 1994.

6 Tancrède C. Role of human microflora in health and disease. Eur $\mathcal{f}$ Clin Microbiol Infect Dis 1992;11:1012-5.

7 Bengmark S. Econutrition and health maintenance-a new concept to prevent GI inflammation, ulceration and sepsis. Clin Nutr 1996;15:1-10.

8 Bengmark S, Gianotti L. Nutritional support to prevent and treat multiple organ failure. World $\mathcal{f}$ Surg 1996;20:474-81.

9 Bengmark S, Jeppsson B. Gastrointestinal surface protection and mucosa Bengmark S, Jeppsson B. Gastrointestinal surface protection
reconditioning. 尹PEN Y Parenter Enteral Nutr 1995;19:410-5.

10 Bengmark S, Larsson K, Molin G. Gut mucosa reconditioning with speciesspecific lactobacilli, surfactants, pseudomucus and fibers-an invited specific lactobacilli, surfactants, pse
review. Biotechnol Ther 1995;5:171-94.

11 Schwartz MN. Hospital-acquired infections: diseases with increasingly limited therapies. Proc Natl Acad Sci USA 1994;91:2420-7.

12 Mora NP, Cofer JB, Solomon H, Goldstein RM, Gonwa TW, Husberg BS, et al. Analysis of severe infections (INF) after 180 consecutive liver transplants: the impact of amphotericin B prophylaxis for reducing the 30.

13 Bergmann OJ, Kilian M, Ellegaard J. Potentially pathogenic microorganisms in the oral cavity during febrile episodes in immunocompromized patients with hematological malignancies. Scand $\mathcal{F}$ Infect Dis 1989;21:41-53.

14 Schiott CR, Briner WW, Loe $\mathrm{H}$. Two year oral use of chlorhexidine in man, II. The effect on the salivary bacterial flora. F Periodont Res 1976;11:14572 .

15 Newman KA, Schimpff SC, Young VM, Wiernik PH. Lessons learned from surveillance cultures in patients with acute non-lymphocytic leukemia. Usefulness for epidemiologic, preventive and therapeutic research. $A m \mathcal{F}$ Usefulness for epidem $1981 ; 70: 423-31$.

16 O'Sullivan MG, Thornton G, O'Sullivan GC, Collins JK. Probiotic bacteria: myth or reality? Trends Food Sci Technol 1992;3:309-14

17 Perdigon G, Alvarez S, Nader de Macias ME, Roux ME, de Ruiz Holgado AP. The oral administration of lactic acid bacteria increases the mucosal intestinal immunity in response to enteropathogens. Fournal of Food Protection 1990;53:404-10

18 Nakaya R. Role of Bifidobacterium in enteric infection. Bifidobacteria Microflora 1984;3:3-9.

19 Corthier G, Dubos F, Raibaud P. Modulation of cytotoxin production by Clostridium difficile in the intestinal tracts of gnotobiotic mice inoculated with various human intestinal bacteria. Appl Environ Microbiol 1985;49: $250-2$.

20 Antoine JM. Validation of health attributes of yogurt. In: Chandra RC, ed. Yoghurt: nutritional and health properties. McLean VA: National Yoghurt Association, 1989:233-40

21 Juven BJ, Meinersmann RJ, Stern NJ. Antiagonistic effects of lactobacilli and pediococci to control intestinal colonization by human enteropathogens in live poultry. I Appl Bacteriol 1991;70:95-103.
22 Hillier SL, Krohn MA, Klebanoff SJ, Eschenbach DA. The relationship of hydrogen peroxide-producing lactobacilli to bacterial vaginosis and genital microflora in pregnant women. Obstet Gynecol 1992;79:369-73.

23 Klebanoff SJ, Hillier SL, Eschenbach DA, Walthersdorph AM. Control of the microbial flora of the vagina by $\mathrm{H}_{2} \mathrm{O}_{2}$-generating lactobacilli. F Infect $D$ is 1991;164:94-100.

24 Pasteur L, Joubert JF. Charbon et septicémie. $C R$ Soc Biol Paris 1877;85:101-15.

25 Metchnikoff E. The prolongation of life. Optimistic studies. London: William Heinemann, 1907.

26 Jack RW, Tagg JR, Ray B. Bactericins of Gram-positive bacteria. Microbiol Rev 1995;59:171-200

27 Wells CL, Maddaus MA, Simmons RL. Proposed mechanisms for the translocation of intestinal bacteria. Rev Infect Dis 1988;10:958-79.

28 Felty AR, Keefer CS. Bacillus coli sepsis: a clinical study of twenty eight cases of blood stream infection by the colon bacillus. FAMA 1924;82:14303.

29 Burd JR, Cody CS, Dunn CL. Immunotherapy of Gram-negative bacterial sepsis. Austin, TX: RG Landes Company, 1992.

30 WHO Scientific Working Group on Monitoring and Management of Bacterial Resistance to Antimicrobial Agents. Geneva: WHO, 1994

31 Sanders ME. Lactic acid bacteria as promotors of human health. In: Goldberg I, ed. Functional foods. New York, London: Chapman and Hall, 1994.

32 Isolauri E, Majamaa H, Arvola T, Rantala I, Virtanen E, Arvilommi H. Lactobacillus casei strain GG reverses increased intestinal permeability induced by cow milk in sucklings. Gastroenterology 1993;105:1643-50.

33 Barrow PA, Brooker BE, Fuller R, Newport MJ. The attachment of bacteria to gastric epithelium of the pig and its importance for the microecology of the intestine. $\mathcal{F}$ Appl Bacteriol 1980;48:147-54.

34 Molin G, Jeppsson B, Johansson M-L, Ahrné S, Nobaek S, Bengmark S. Numerical taxonomy of Lactobacillus spp associated to healthy and diseased mucosa of the human intestines. I Appl Bacteriol 1993;74:314-23.

35 Chanviere G, Barbat A, Fourniat J, Servin AL. Adhesion of Lactobacillus onto cultured human enterocyte-like cell lines Caco-2 and HT-29. Comparison between human and non human strains. In: Les laits fermentes. Actualité de la recherche. John Libbey Eurotext Ltd, 1989.

36 Adlerberth I, Ahrné S, Johansson M-L, Molin G, Hansson LÅ, Wold AE. A mannose-specific adhesion mechanism in Lactobacillus plantarum conferring binding to the human colonic cell line HT-29. Appl Environ Microbiol 1996;62:2244-51.

37 Bouhnik Y, Pochart P, Marteau P, Arlet G, Goderel I, Rambaud JC. Fecal recovery in humans of viable Bifidobacterium sp. ingested in fermented milk. Gastroenterology 1992;102:875-8.

38 Fuller R. Problems and prospectives. In: Fuller R, ed. Probiotics: the scientific basis. London, New York, Tokyo, Melbourne, Madras: Chapman and Hall, 1992:377-86.

39 Roberfroid $\mathrm{MB}$, Gibson GR. Colonic microflora-nutrition and health. Workshop on colonic microflora: nutrition and health, ILSE Europe, Barcelona, 1994. Nutrition Reviews (in press).

40 Teuber $\mathrm{M}$. The influence of fermentation on the nutritional quality of diary products: facts and fiction. The World of Ingredients: Fournal of the Practising products: facts and fiction. Thologists 1995:43-6.

41 Bernet MF, Brassart D, Neeser JR, Servin AL. Lactobacillus acidophilus LA 1 binds to cultured human intestinal cell lines and inhibits cell attachment and cell invasion by enterovirulent bacteria. Gut 1994;35:483-9.

42 Elo S, Saxelin M, Salminen S. Attachment of Lactobacillus casei strain GG to human colon carcinoma cell line Caco-2: comparison with other diary strains. Letters in Applied Microbiology 1991;13:154-6.

43 Goldin BR, Gorbach SL, Saxelin M, Bakarat S, Gualtieri L, Salminen S. Survival of Lactobacillus species (strain GG) in human gastrointestinal tract. Dig Dis Sci 1992;37:121-8.

44 Ling WH, Korpela R, Mykkenän H, Salminen S, Hänninen O. Lactobacillus strain GG supplementation decreases colonic hydrolytic and reductive enzyme activities in healthy female adults. $\mathcal{F}$ Nutr 1994;124:18-23.

45 Halpern GM, Wruwing KG, Van de Water J, Keen CL, Gershwin ME. Influence of long-term yoghurt consumption in young adults. Int f Immunother 1991;7:205-10.

46 Lee Y-K, Salminen S. The coming age of probiotics. Trends in Food Science .

47 Isolauri E, Kaila M, Mykkänen H, Ling W-H, Salminen S. Oral bacteriotherapy for viral gastroenteritis. Dig Dis Sci 1994;39:2595-600.

48 Majamaa $H$, Isolauri E, Saxelin M, Vesikari T. Lactic bacteria in the treatment of acute rotavirus gastroenteritis. I Pediatr Gastroenterol Nutr 1995;20:333-8.

49 Millar MR, Bacon C, Smith SL, Walker V, Hall MA. Enteral feeding of premature infants with Lactobacillus GG. Arch Dis Child 1993;69:483-7.

50 Sepp E, Mikelsaar M, Salminen S. Effect of administration of Lactobacillus casei strain GG on the gastrointestinal microbionta of newborns. Microbiol Ecol Health Dis 1993;6:309-14.

51 Isolauri E, Juntunen $M$, Saxekin $M$, Vesikari T. Lactic acid bacteria in the treatment of acute

52 Oksanen P, Vapaatalo H, Salminen S, Saxelin M, Halmilainen P, IhantoloVormisto A, et al. Prevention of traveller's diarrhea by Lactobacillus GG. Ann Med 1990;22:53-6.

53 Gorbach SL, Chang T, Goldin B. Successful treatment of relapsing Clostridium difficile colitis with Lactobacillus GG. Lancet 1987;ii:1519.

54 Biller JA, Katz AJ, Flores AF, Buie TM, Gorbach SL. Treatment of recurrent Clostridium difficile colitis with Lactobacillus GG. $\mathcal{F}$ Pediatr Gastroenterol Nutr 1995;21:224-6.

55 Saxelin M, Chuang N-H, Chassy B, Rautelin H, Mäkelä H, Salminen S, et al. Lactobacilli and bacteremia in Southern Finland 1989-1992. Clin Infect Dis 1996;22:564-6.

56 Donohue DC, Salminen S. Safety of probiotic bacteria. Asia Pacific 7 Clin Nutr 1996;5:25-8.

57 Ahrné S, Johansson M-L, Molin G. Intestinal passage of Lactobacillus rhamnosus 6594 after oral administration in fermented milk. Netherlands Milk and Dairy fournal 1995;49:201-5.

58 Lindgren SE, Dobrogosz WJ. Antagonistic activities of lactic acid bacteria in food and feed fermentations. FEMS Microbiol Rev 1990;87:149-64.

59 Vescovo M, Torriani S, Dellagrio F, Bottazzi V. Basic characteristics, ecology and application of Lactobacillus plantarum: a review. Ann Microbiol Enzymol 1993;43:261-84. 
60 Nes IF. Plasmid profiles of ten strains of Lactobacillus plantarum. FEMS Microbiol Lett 1984;21:359-61.

61 McDonald LC, Fleming HP, Hassan HM. Acid tolerance of Leuconostoc mesenteroides and Lactobacillus plantarum. Appl Environ Microbiol 1990;56:2120-4.

62 Montel M-C, Champomier M-C. Arginine catabolism in Lactobacillus sake isolates from meat. Appl Environ Microbiol 1987;534:2683-5.

63 Jónsson S, Clausen E, Raa J. Amino acid degradation by a Lactobacillus plantarum strain from fish. System Appl Microbiol 1983;4:148-54.

64 Osborne DL, Seidel ER. Microflora-derived polyamines modulate obstruction-induced colonic mucosal atrophy. Am f Physiol 1989;256: G1049-57.

65 Wright CE, Rees DD, Moncada S. Protective and pathological role of nitric oxide in endotoxin shock. Cardiovasc Res 1992;26:48-57.

66 Duncan C, Dougall H, Johnston P, Green S, Brogan R, Leifert C, et al. Chemical generation of nitric oxide in the mouth from the enterosalivary circulation of dietary nitrate. Nat Med 1995;1:546-51.

67 Lundberg JON, Weitzberg E, Lundberg JM, Alving K. Intragastric nitric oxide production in humans: measurements in expelled air. Gut oxide production

68 Spitz JC, Taveras M, Hecht G, Taveras M, Aoys E, Alverdy J. The effect of dexamethasone administration on rat intestinal permeability: the role of dexamethasone administration on rat intestinal perm

69 Johansson M-L, Molin G, Jeppsson B, Nobaek S, Ahrné S, Bengmark S Administration of different Lactobacillus strains in fermented oatmeal soup; in vivo colonization of human intestinal mucosa and effect on the indigenous flora. Appl Environ Microbiol 1993;59:15-20.

70 Falkow S, Isberg RR, Portney DA. The interaction of bacteria with mammalian cells. Annu Rev Cell Biol 1992;8:333-63.

71 Ashkenazi S, Dinari G, Mirelman D. Gastrointestinal infections. Front Gastrointest Res 1986;13:284-92.

72 Van Deventer SJH, Ten Cate JW, Tytgat GNJ. Intestinal endotoxemia: clinical significance. Gastroenterology 1988;94:835-41.

73 Niedermann MS, Merrill WW, Polomski LM, Reynolds HY, Gee JB. Influence of sputum IgA and elastase on tracheal cell bacterial adherence. $\mathrm{Am}$ Rev Respir Dis 1986;133:255-60.

74 Alverdy JC, Spitz J, Hecht G, Ghandi S. Causes and consequences of bacterial adherence to mucosal epithelia during critical illness. New Horizons rial adherence to

75 Todd TR, Franklin A, Mankinen-Irvin P, Gurman G, Irvin RT. Augmented bacterial adherence to tracheal epithelial cells is associated with Gram-negative pneumonia in an intensive care unit population. Am Rev Respir Dis 1994;140:1585-9.

76 Spitz JC, Ghandi S, Tavares M, Aoys A, Alverdy JC. Characteristics of the intestinal epithelial barrier during dietary manipulation and glucocorticoid stress. Crit Care Med 1996;24:635-41.

77 Alverdy JC, Aoys E, Moss GS. Total parenteral nutrition promotes bacterial translocation from the gut. Surgery 1988;104:185-9.

78 Kudsk KA, Groce MA, Fabian TC, Minard G, Tolley EA, Poret HA. Enteral versus parenteral feeding: effects on septic morbidity after blunt and penetrating abdominal trauma. Ann Surg 1992;215:503-13.

79 Moore FA, Feliciano DV, Andrassy RJ, McArdle AH, Both FV, Morgenstein-Wagner TB, et al. Early enteral feeding compared with parenteral, reduces postoperative septic complications. The results of a meta-analysis. Ann Surg 1991;216:172-82.

80 Daly JM, Lieberman MD, Goldfine J, Shou J, Weintraub F, Rosato EF, et al. Enteral nutrition with supplemental arginine, RNA, and omega-3 fatty acids in patients after operation: immunologic, metabolic and clinical outcome. Surgery 1992;112:56-67.

81 Daly JM, Weintraub FN, Shou J, Rosato EF, Lucia M. Enteral nutrition during multimodulary therapy in upper gastrointestinal cancer patients. Ann Surg 1995;221:327-38.

82 Braga MN, Vignali A, Gianotti L, Cestari A, Profili M, Carlo VD, et al. Immune and nutritional effects of early enteral nutrition after major abdominal operations. Eur F Surg 1996;162:105-12.

83 Kemen M, Senkal M, Homann H-H, Mumme A, Dauphin A-K, Baier J. Early postoperative enteral nutrition with arginine-omega-3 fatty acids and ribonucleic acid-supplemented diet versus placebo in cancer patients: an immunological evaluation of IMPACT Crit Care Med 1995;23:652-9.

84 Bower RB, Cerra FB, Bershadsky B, Licari JJ, Hoyt DB, Jensen GL, et al. Early enteral administration of a formula (IMPACT) supplemented with arginine, nucleotides, and fish oil in intensive care unit patients: results of a multicenter, prospective, randomized, clinical trial. Crit Care Med 1995;23: 436-49.

85 Bengmark S, Gianotti L. Immunonutrition-a new aspect in the treatment of critically ill patients. In: Gullo, A, ed. Anaesthesia, pain, intensive care and emergency medicine-APICE. Proceedings of the 10th Postgraduate Course in Critical Care Medicine; Nov 13-19 1994; Trieste. Berlin: Springer Verlag, 1995.

$86 \mathrm{Alm}$ L. The therapeutic effects of various cultures-an overview. In Robinson RK, ed. Therapeutic properties of fermented milks. London, New York: Elsevier Applied Science, 1991:45-64

87 Raibaud P. Bacterial interaction in the gut. In: Fuller R, ed. Probiotics: the scientific basis. London, New York, Tokyo, Melbourne, Madras: Chapman and Hall, 1992:9-28.

88 Stark PL, Lee A. The microbial ecology of the large bowel of breast-fed and formula-fed infants during the first year of life. 7 Med Microbiol 1982;15:189-203.

89 Simhon A, Douglas JR, Drasar BS, Soothill JF. Effect of feeding on infant's faecal flora. Arch Dis Child 1982;57:54-8.

90 Balmer SE, Wharton BA. Diet and faecal flora in the newborn: breast milk and infant formula. Arch Dis Child 1989;64:1672-7.

91 Gothefors L, Carlsson B, Ahlstedt S, Hansson LÅ, Winberg J. Influence of maternal gut flora and colostral and cord serum antibodies on presence of Escherichia coli in faeces of the newborn infant. Acta Paediatr Scand 1976; 65:225-32.

92 Wold AE, Hansson LÅ. Defense factors in human milk. Curr Opin Gastroenterol 1994;10:652-8.

93 Lencner AA, Lencner ChP, Mikelsaar ME, Tjuri ME, Toom MA, Väljaots $\mathrm{ME}$, et al. Die quantitative Zusammensetzung der Lactoflora des Verdauungstrakts vor und nach kosmischen Flügen unterschiedlicher Dauer. Die Nahrung 1984;28:607-13.

94 Spera Jr RV, Farber BF. Multidrug-resistant Enterococcus faecium. An untreatable nosocomial pathogen. Drugs 1994;48:678-88.

95 Mainous MR, Lipsett PA, Stevensen M. Enterococcal bacteremia in the SICU: does vancomycin affect outcome [abstract]. Surgical Infection Society Meeting, Milwaukee, March 1996.

96 Zervos MJ, Kauffman CA, Therasse PM, Bergman AG, Mikesell TS, Schaberg DR. Nosocomial infection by gentamycin-resistant Streptococcus faecalis. Ann Intern Med 1987;106:687-91.

97 Leclercq R, Derlot E, Duval J, Courvalin P. Plasmid-mediated resistance to vancomycin and teicoplanin in Enterococcus faecium. N Engl f Med 1988; 319:157-61.

98 Murray BE, Singh KV, Markowitz SM, Lopardo HA, Patterson JE, Zervos $\mathrm{MJ}$, et al. Evidence for clonal spread of a single strain of beta-lactamaseproducing Enterococcus (Streptococcus) faecalis to six hospitals in five states. F Infect Dis 1991;163:780-5.

99 Bates J, Jordens Z, Selkon JB. Evidence for an animal origin of vancomycinresistant enterococci. Lancet 1993;342:490-1.

100 Frieden TR, Munsiff SS, Low DE, Willey BM, Williams G, Faur Y, et al. Emergence of vancomycin-resistant enterococci in New York City. Lancet 1993;342:76-9.

101 Pallares R, Pujol M, Pena C, Ariza J, Martin R, Gudil F. Cephalosporins as risk factor for nosocomial Enterococcus faecalis bacteremia. Arch Intern Med 1993;151:1581-6.

102 Boyce JM, Opal SM, Chow JW, Zervos MJ, Potter-Bonoe G, Sherman CB, et al. Outbreak of multidrug-resistant Enterococcus faecium with transferable vanB Class vancomycin resistance. $\mathscr{f}$

103 Boyce JM, Mermel LA, Zervos MJ, Rice LB, Potter-Bynoe G, Georgio Ch, Medeiros A. Controlling vancomycin-resistant enterococci. Infect Control Hosp Immunol 1995;16:634-7 